\title{
Social Exclusion of Farmers of Arid Areas
}

\author{
Uzooba Hureem ${ }^{1}$ ¿ \\ Zainab Butt ${ }^{2}$ \\ 'Staff-Sociologist at Punjab Economic Research Institute (PERI), Lahore, Pakistan \\ Email:uzooba.hureem@peri.punjab.gov.pk Tel:+92-042-99233441 \\ ${ }^{\circ}$ Lecturer at Government Degree College for Women, Mustafabad, Lahore, Pakistan \\ Email:buttzainab@gmail.com Tel:+92-0300-484.0810 \\ ( Corresponding Author)
}

\begin{abstract}
In the arid parts of Pakistan, the farmers are socially excluded owing to their lack of access to technology and unaffordability of farm inputs. Two thirds of Pakistan is arid and dependent on rain. Irregular patterns of rainfall also play havoc with agricultural productivity and ultimately affects GDP \& food security. The purpose of this research was to observe the existence of social exclusion of the small farmers from different dimensions and to study their neutral relationship. Case studies of 15 farmers were conducted to get information about social exclusion from different dimensions and their relationship. Analysis of the data supports the hypothesis of farmers' social exclusion along a host of dimensions such as education, infrastructure and technological access. The extent of social exclusion is significantly more in the case of farmers living in disadvantaged areas. Most of the farmers do not have enough means to enhance their yield; lack of education, lack of access to adequate water resources and unawareness about modern technologies which is the major contributor to their exclusion.
\end{abstract}

Keywords: Exclusion, Farm inputs, Yield, Productivity, GDP, Food insecurity, Arid area.

Citation | Uzooba Hureem; Zainab Butt (2018). Social Exclusion of Farmers of Arid Areas. Asian Journal of Social Sciences and Management Studies, 5(1): 8-15.

History:

Received: 11 December 2017

Revised: 15 January 2018

Accepted: 22 January 2018

Published: 26 January 2018

Licensed: This work is licensed under a Creative Commons

Attribution 3.0 License (cc)

Publisher:Asian Online Journal Publishing Group
Contribution/Acknowledgement: Both authors contributed to the conception and design of the study.

Funding: This study received no specific financial support.

Competing Interests: The authors declare that they have no conflict of interests.

Transparency: The authors confirm that the manuscript is an honest, accurate, and transparent account of the study was reported; that no vital features of the study have been omitted; and that any discrepancies from the study as planned have been explained.

Ethical: This study follows all ethical practices during writing.

\section{Contents}

1. Introduction

2. Theory of Social Exclusion

3. Research Locale

4. Methodology......

10

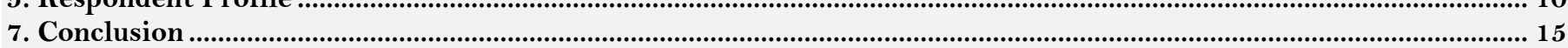

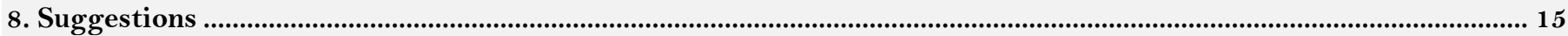

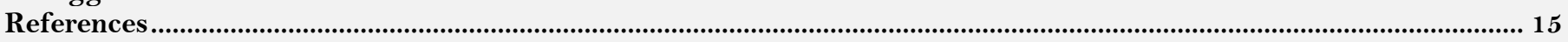

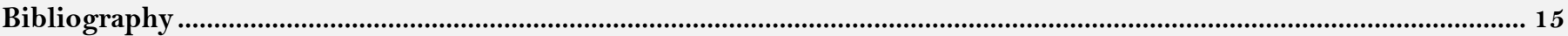




\section{Introduction}

Social Exclusion is a broader concept, encompassing not only low material means but also the inability to participate effectively in economic, social, political and cultural life and in some ways alienation and distance from main stream of society (Atkinson and Hills, 1998).

In the arid parts of Pakistan, the farmers are socially excluded owing to their lack of access to technology and high prices of pesticides which results in less productivity and ultimately causes food insecurity. This also affects the GDP. Two third land of Pakistan is arid and dependent on rain. Irregular patterns of rainfall also play havoc with agricultural productivity.

The purpose of this research was to observe the existence of social exclusion among small farmers from different dimensions and to study their neutral relationship. The key question is to determine the extent to which social exclusion and the problems confronted by the small farmers of Pakistan prevail?

In the past, researches have conducted on the role of farmers in agricultural and economic sector of several countries. Abbas et al. (2003) identified that education had a highly significant relationship with farmer's awareness about pesticides and its usage to enhance productivity. Badar et al. (2007) conducted a study analyzing small farmers and the study results showed that agriculture labour of Punjab is playing a significant role in increasing agricultural production. However, there is need to equipped them with modern technologies and relevant agricultural trainings to enhance more productivity in agriculture sector. Given this brief introduction, the following are the objectives of the case study:

1. To observe the existence of social exclusion in the five Villages of Chakwal District.

2. To identify different dimensions of social exclusion of farmers, and

3. To determine the extent of different elements of exclusion.

\section{Theory of Social Exclusion}

Arjan de Haan ${ }^{1}$ states that, exclusion can be social, political, cultural, or emotional. These forms of exclusion may frequently interact: racial minorities are commonly economically disadvantaged as well as being politically and culturally marginalized. Here the theory is included for the exclusion of social and economic opportunities of the farmers. Economically they do not have sufficient production for sale. Socially they are not connected to agricultural organization, lacking education and means of communication.

\subsection{Conceptual Model}

The basic conceptual model as shown below is structured by using the concepts of social exclusion of farmers by elaborating how social exclusion takes place in socio cultural context of our society. Social exclusion is viewed as multi-dimensional concepts such as social, cultural, economic and political with reference to the small farmers.

Table-1. Conceptual Model

\section{Social Exclusion of small Farmers}

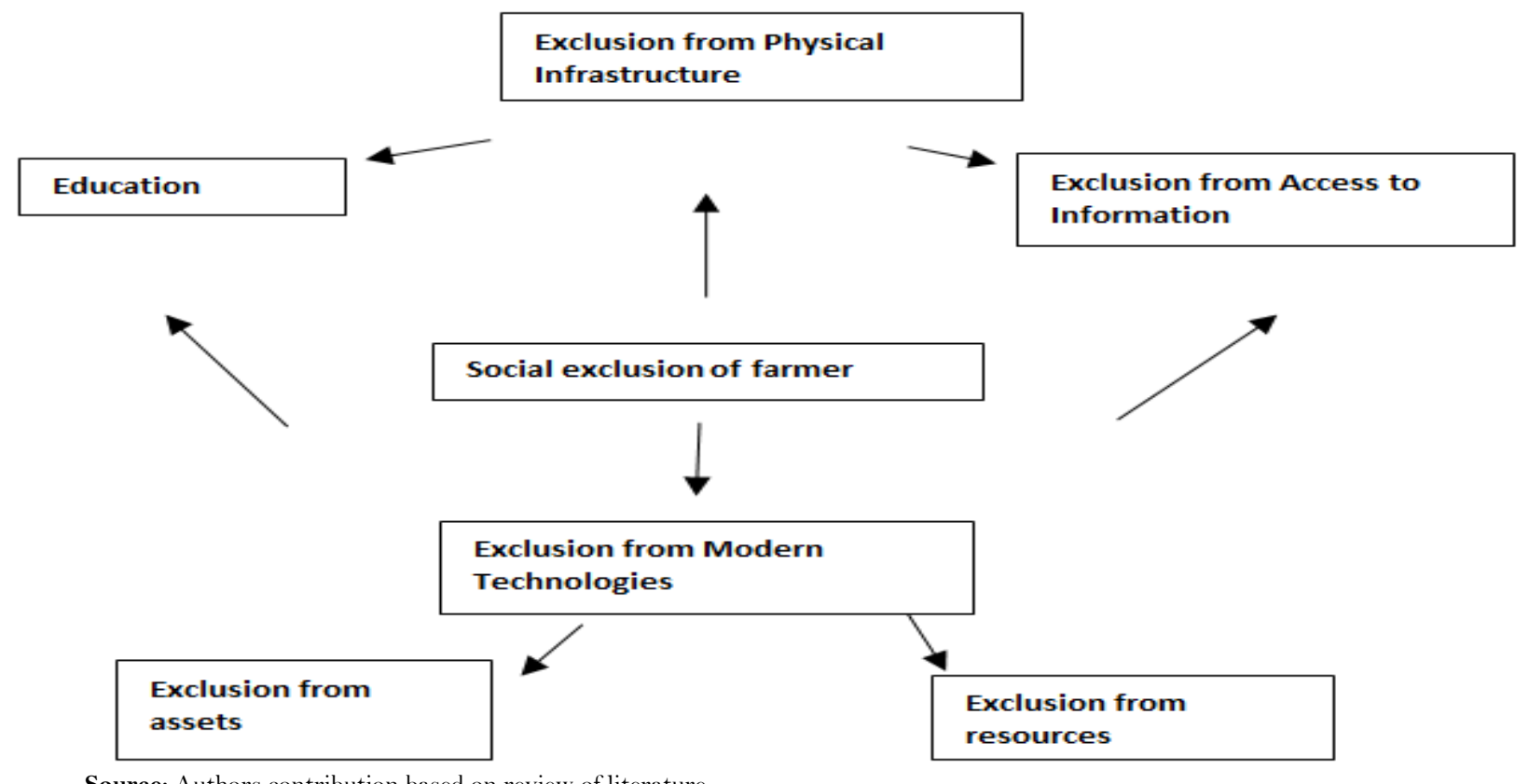

Social exclusion of farmers is occurring due to different elements. These elements are sub concepts which are stated as under \& described in Table 1. These include exclusion from:

i. Education

ii. Agricultural assets

iii. Modern technologies

iv. Resources

v. Physical Infrastructure

vi. Access to Information

\footnotetext{
${ }^{1}$ Social Exclusion: Enriching the understanding of Deprivation
} 
Table-2. Indicators to Measure Social Exclusion Dimensions

\begin{tabular}{l|l}
\hline \multicolumn{1}{c}{ Dimensions } & \multicolumn{1}{c}{ Indicators } \\
\hline Exclusion from Modern Technologies & (Pesticides, Chemicals, Fertilizer and biotechnology) \\
\hline Exclusion from Resources & (Electricity, Water) \\
\hline Exclusion from Physical Infrastructure & (Roads, transport, motors and turbines) \\
\hline Exclusion from Access to Information & (Newspapers, Radio, TV and Phone) \\
\hline Exclusion from Education & (Below Primary, Primary, Middle, Metric and higher) \\
\hline $\begin{array}{l}\text { Exclusion from Agricultural } \\
\text { Machinery }\end{array}$ & (Tractors, thrashers, Sheller, seed graders Drills, hand sprayers, trailer \& cutter etc.) \\
\hline Farm Size & (From 1 acre to 20 acres.) \\
\hline Note: 1 Acre $(\mathrm{B})=8$ Kanal $=8 \times 54.4 .8 \mathrm{ft.}{ }^{2}=43558.4 \mathrm{ft} .{ }^{2}$ (since, 1 Kanal $\left.=54.4 .8 \mathrm{ft.}{ }^{2}\right)$
\end{tabular}

Note: 1 Acre $(B)=8$ Kanal $=8$ x $5444.8 \mathrm{ft.} .^{2}=43558.4 \mathrm{ft} .{ }^{2}\left(\right.$ since, 1 Kanal $\left.=5444.8 \mathrm{ft} .{ }^{2}\right)$

Source: http://pakagrifarming.blogspot.com/2012/09/agricultural-land-measuring-units-in.html

\section{Research Locale}

Chakwal is an arid district and the land is mainly hilly, this area has a shortage of irrigation systems and water sources for agriculture. More than half of the population is involved in agriculture. Mustard, Wheat, Grains, Sesame, Peanuts and Tara Mira are major crops of this area. Mostly agricultural subsistence dependent on rainfall; and villages do not have any irrigation system.

\section{Methodology}

Case studies were conducted in five villages/tehsils of Chakwal:

i. $\quad$ Mureed

ii. Balkassar

iii. Dhakko

iv. Maingan

v. Dhokdandi

Researchers have used purposive sampling because this sampling framework is broadly used for the identification and selection of information-rich cases in the qualitative research. It also identifies particular types of cases on judgment bases. Sample size of the research is $\mathbf{1 5}$ farmers from the rural areas of Chakwal.

Case studies were conducted to measure the social exclusion of farmers. Case study method was selected because

- It helps researcher to connect the micro level, or the actions of individual people.

- It is useful for both educated and uneducated person.

- Respondent is not bound in particular options.

- Respondent can easily express what he wants to convey.

Problems of the rural farmers related to the field cannot be understood without case studies. That is why case studies of the farmers was conducted to understand their activities related to the cultivation and production of their lands in detail by using the open-ended questionnaire. Researchers used the interview guide and developed themes to examine and measure common features at one period of time. The semi structured interview guide provides in depth information of the data and comprised of 40 questions.

\section{Respondent Profile}

\subsection{Demographics of the Farmers}

All farmers were male and were married. Average number of children was 7. All farmers cultivated their own farmland. The land holding criteria was 1 acre to 20 acres. The major crops are wheat, pulses, gram, peanuts and melon. Ten respondents cultivated half of their total land. Most of the farmers cultivated wheat.

Pakistani rural sector has joint and extended joint family system. It means more than one family is living together. According to the data (see Figure 1) 67 percent respondents are living in joint family system. Food requirement of all the family members is fulfilled by the gained production. Everything is shared between all family members including household expenditures and cost of production. They practice agriculture subsistence together to produce enough yield. Only 33percent farmers belong to nuclear family system compromised on married couple and their children and solely responsible for their own subsistence.

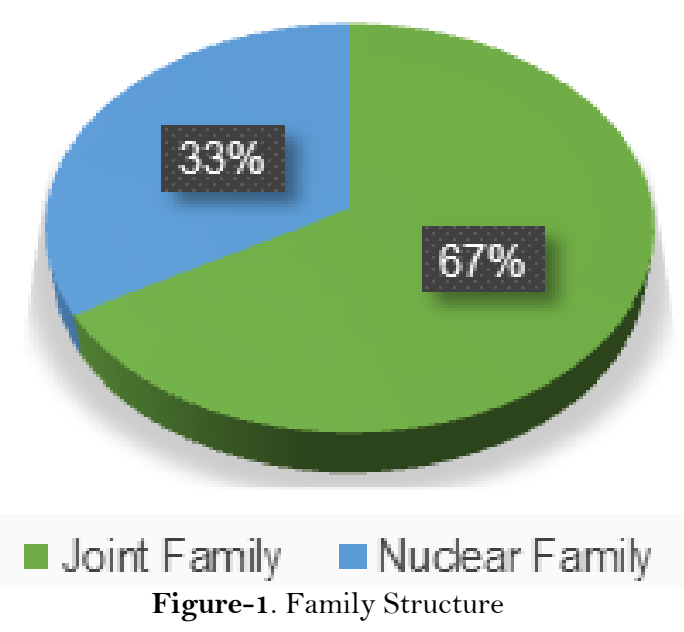


Data (see Figure 2) depicts that most of the respondents have big family size of more than 9 children. While only 2 farmers have small family size below 4 number of children. Average household size of farmers is 8 . The smallest household size is 4 . One respondent had 15 children.

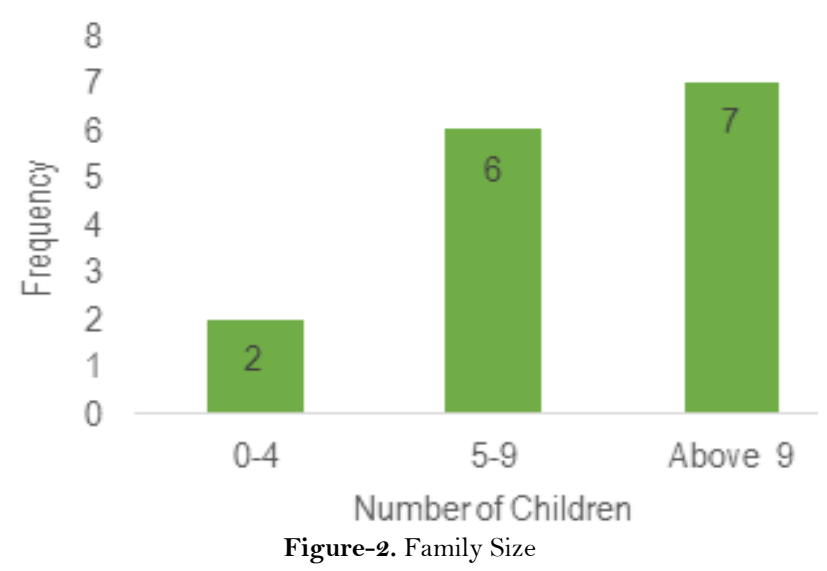

Larger family sizes forces farmers to enhance their crop productivity so that they can meet needs of their family and bear cost of production as well. But due to small land holding, little cultivated area and paddy productivity they have to face many difficulties to satisfy the necessities of their families.

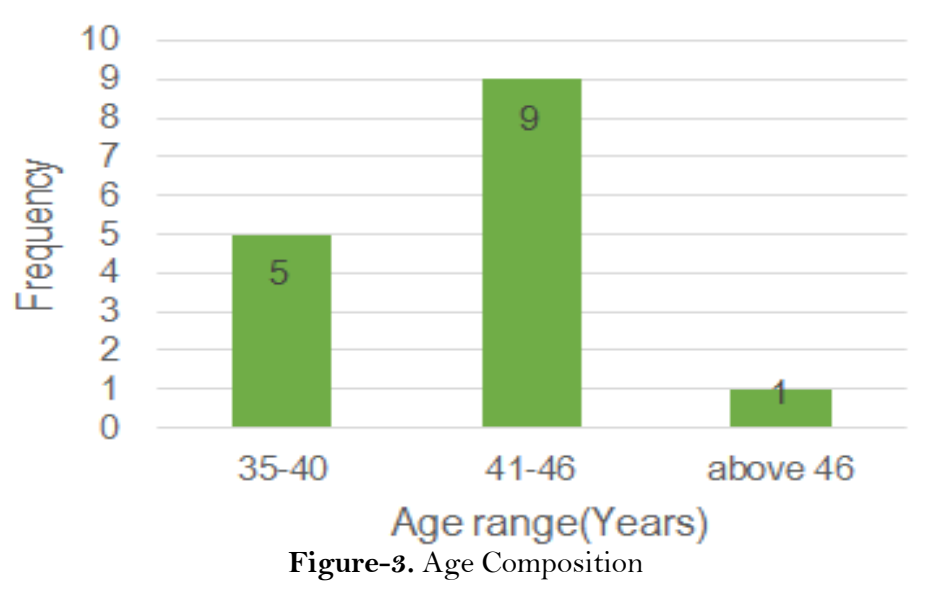

The age of the respondents was from 35 to 55 years (see Figure 3). However most of the farmers belongs to above 40 age group. Only 5 respondents fall between 35-40 age group. Data illustrates that majority of the farmers are middle age. Still they want to get trainings and scientific knowledge to enhance crop productivity. they don't have enough energy and capacity to use traditional farming methods and enhance productivity.

Education is necessary to understand the latest farming techniques, to adopt modern technology and to move from traditional farming practices to modern farming methods. But the data (see Figure 4) depicts that most of the respondents were uneducated and four had only passed primary. These respondents do not have enough education to understand biotechnology, latest farming techniques and to apply these methodologies. Lack of education is an obstacle in learning new skills and trainings. Only two respondents have completed their high school and they were using chemical seeds, pesticides and fertilizer to some extent. But rest of the farmers were reluctant to adopt latest farming methods.

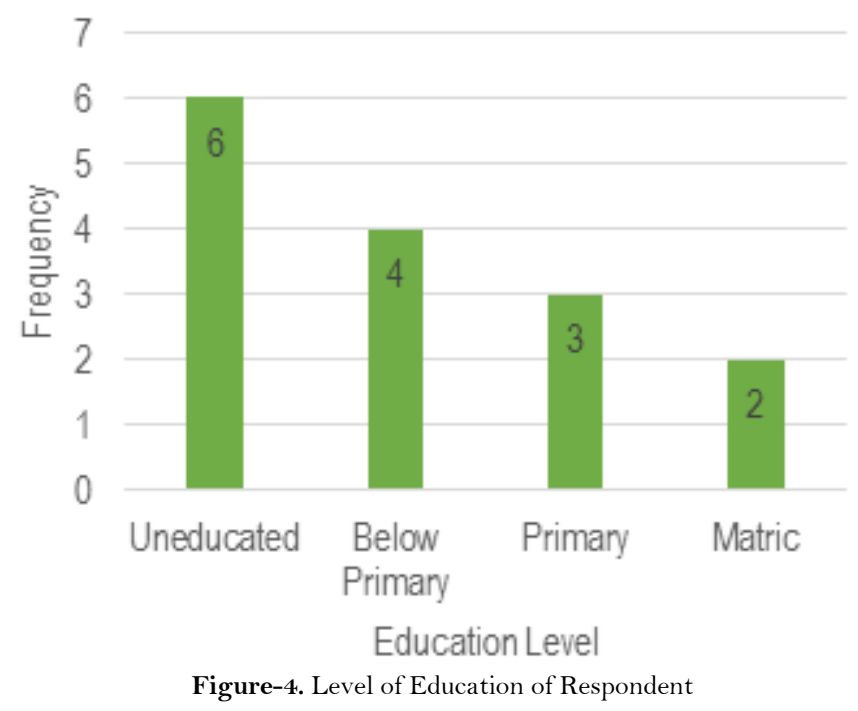

\subsection{Farming Patterns of the Farmers}

Data is gathered from the small farmers of land holding ranges from 1 acre to 20 acres. Most of the cases are the owners of 11 to 15 acres of land (see Figure 5). Only one farmer had land holding area of above 16 acres. Moreover, holding large area of land does not mean that it will yield higher productivity. Total production is dependent on how much land is cultivated from the total land and how many times per year? Majority of the 
respondents cultivated only half area of their land and half remained uncultivated due to scarcity of water resources and high cost of production.

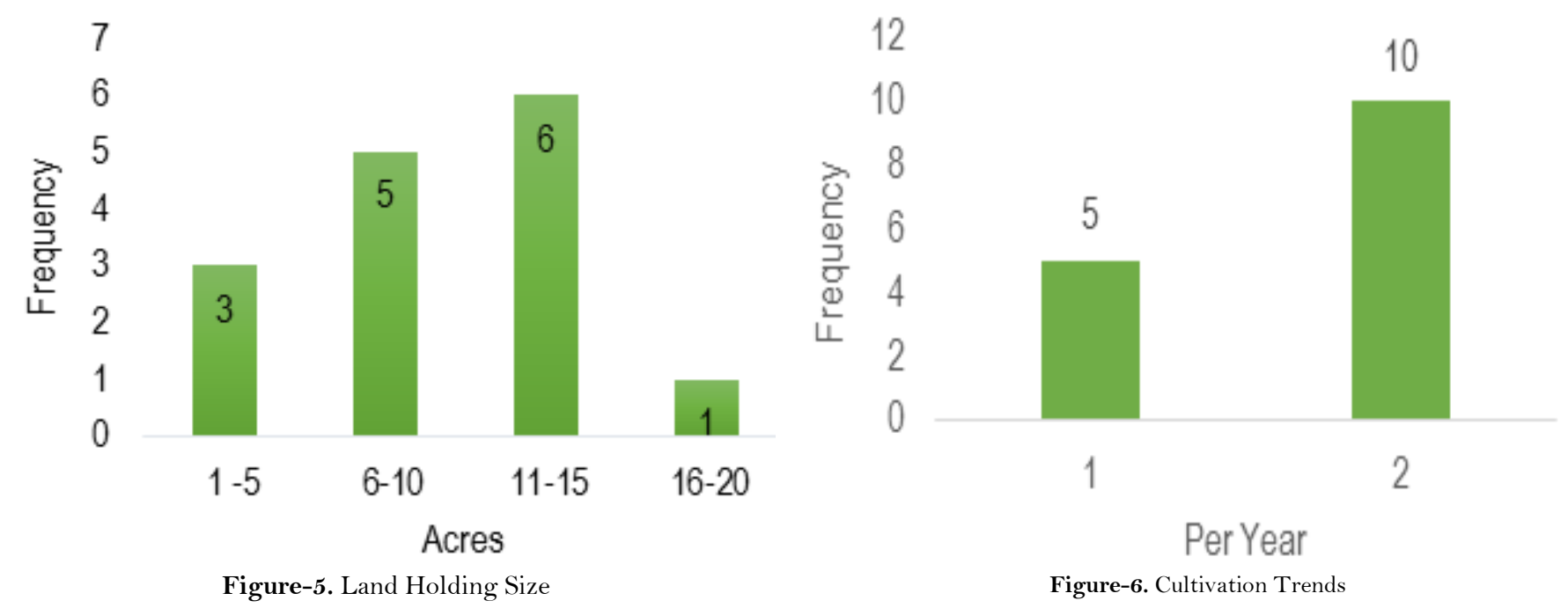

Data illustrates that (see Figure 6) most of the farmers cultivated their land two times per year. Most of the respondents cultivated wheat, peanut, gram and pulses. These are seasonal crops which are cultivated in Rabi ${ }^{2}$ and Kharif ${ }^{3}$ season. Ten respondents cultivated both Rabi and Kharif crops. This raised their intensity of cultivation to twice a year as compared to those who cultivated single season crop.

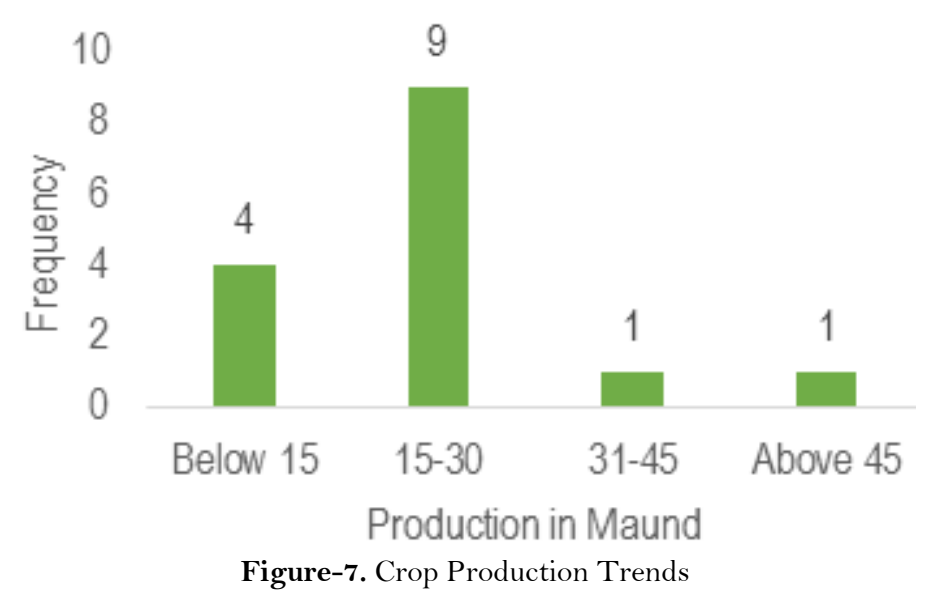

Data (see Figure 7) highlights that most of the farmers have gained 15 to 30 maund of their production which can be one of the wheat, pulse, gram and peanut. Few respondents have below 15 maund crop production per acre. A single farmer had 55 maund production of wheat and gram per acre because his land holding size was 17.5 acres. But he cultivated 9-acre land. Only those farmers who have large land holding, use good quality seeds, fertilizer and pesticides thus yielding higher production as compare to others. Besides all these factors, lack of water resources played a big role in low productivity of this area.

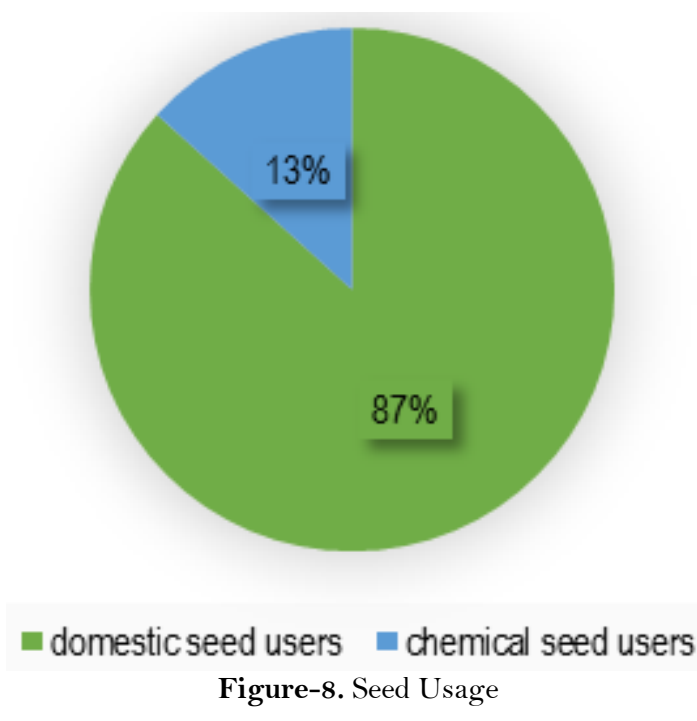

The use of farm inputs particularly hybrid seeds is very effective in enhancing productivity. However, data shows that (see Figure 8) 87 percent respondents used domestic seeds for sowing which cannot combat pest attacks and enhance productivity. They also have to reserve half of the production for the sowing of next crop; resulting in

${ }^{2}$ The term Rabi means "spring" and the Rabi crops are grown between the months mid-November to April. Major Rabi crop is wheat.

Source: http://agrinfobank.blogspot.com/2013/04/rabi-and-kharif-crops.html

${ }^{s}$ Kharif crops are usually sown with the beginning of the first rains towards the end of May. Major kharif crops are maize, pulses and peanut.

Source: http://agrinfobank.blogspot.com/2013/04/rabi-and-kharif-crops.html 
less production that cannot move to market for sale. Majority of the respondents don't have financial capacity to purchase chemical seeds and they also lack understanding of the importance of hybrid seeds in the productivity perspective. It is a form of exclusion from access to chemical seeds and lack of awareness about their benefits related to crops 'productivity and food security. Only 13percent farmers use chemical seeds and they also lack understanding about various types of seeds, quantity and quality of seeds, optimal timing to sow seeds and all those factors which can contribute to higher productivity.

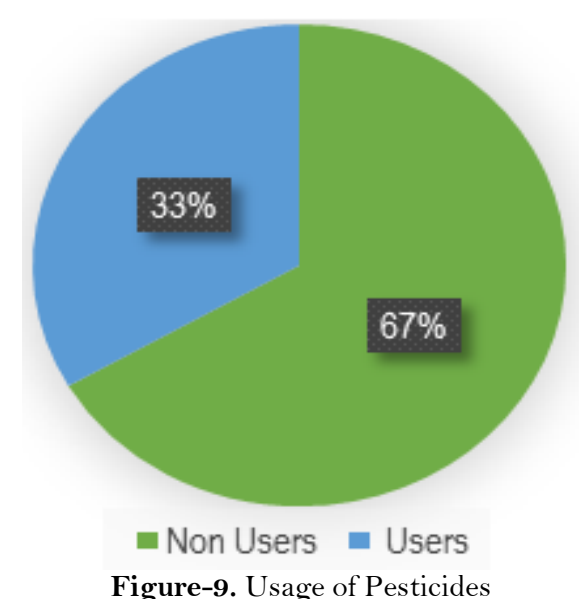

Despite the fact that pesticides play vital role in crop protection 67 percent respondents don't use pesticides to protect crops against pest attacks (see Figure 9) Farmers also complain about the absence of any awareness campaign on behalf of agricultural department and pesticide companies in their area to create awareness about protection of crops from harmful insects. Owing to lack of training farmer don't know about the proper dosage of pesticide, crops diseases and best fitted pest and time for the protection of their crops. That's why they avoid using it and stick to traditional farming methods which ultimately affect the average yield productivity. Data also demonstrates that very few farmers use pesticides to protect their crops and that too without any training or accurate knowledge. Meanwhile, farmers also complained about the non-availability of spray and high prices of pesticides.

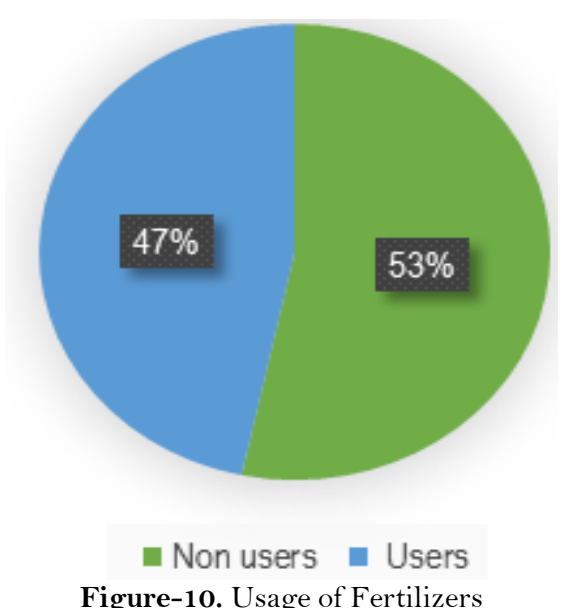

Fertilizers are not widely used by the farmers, as illustrated by the data (see Figure 10) 53 percent respondents do not use fertilizers like potash, urea and phosphorus etc. They reported their lack of affordability as the major reason behind it. Those who sow, also complained about its non-availability and high prices. One of the factors of not using of fertilizer was that, it needs water otherwise it causes damages crops. Hence, they use fertilizer in the rainy season. Furthermore, farmers don't have training or enough knowledge about the proper use of fertilizer because imbalanced use of fertilizer not only reduce the crops yields but also leads to excessive economic loss. Few respondents have used fertilizers \& reported awareness about its proper usage.

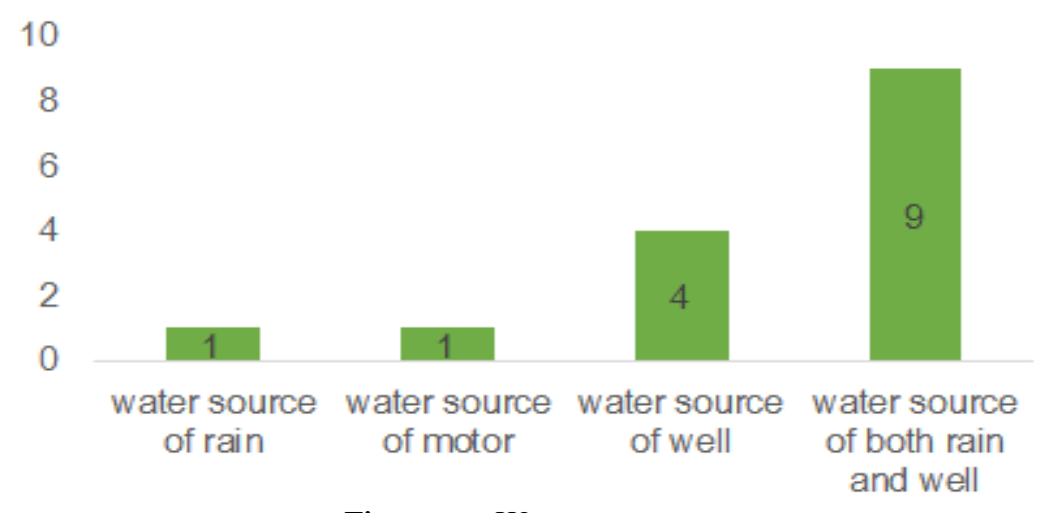

Figure-1 1. Water resources

Analysis depicts that (see Figure 11) water resource is a hot issue for farmers which was a major cause of low level food production and food insecurity amongst them. Most of the respondents explained that their utmost problem is lack of water resources. Given this water scarcity their crops remain at risk of being ruined. When 
farmers sow fertilizer they need water immediately otherwise crops gets destroyed if sufficient water is not available in a timely manner. That's why farmers neither use fertilizer widely nor cultivate their whole land. Majority of the farmers are dependent on wells, tube wells and rain water for irrigation. Meanwhile lack of water resources adversely effects average yield productivity.

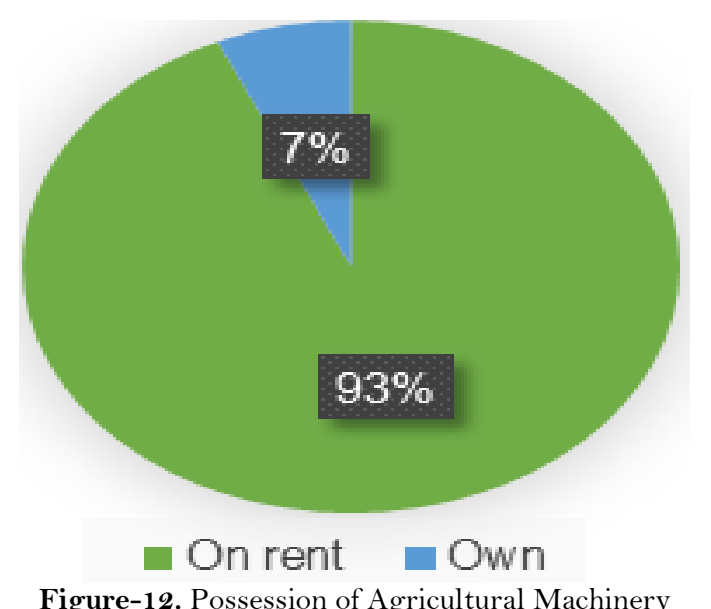

Rent a tractor, drill machine, cutter, thresher, turbine, motor and trailer are very common amongst farmers which is the exclusion from basic cultivation implements. Data reveals that (see Figure 12) very few farmers have their own tractor, drill machine and cutter for cultivation. The farmers reporting lack of availability of these implements are small landholders. Whereas 93 percent farmers don't have agricultural machinery for cultivation purposes. Results reveal that those farmers who do not have their agricultural machinery report lower level of production. When farmers do not have their own tractors, drill machines and trailer chances to get sufficient production decreases that cannot meet the needs of market. Furthermore, due to the absence of these assets they have to face difficulty to access the market to sell their yield.

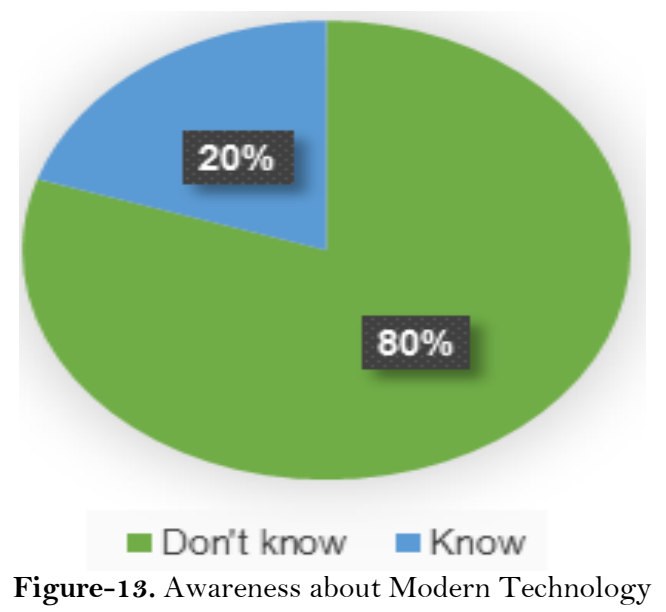

Most of the farmers do not understand the importance of modern techniques in agriculture sector see Figure 13. Only 20 percent of the farmers have information about latest farming methods or bio technology but lack awareness of its application. They are excluded from scientific training, latest farm practices and information to produce more food and achieve maximum yield. Very few farmers have knowledge about progressive farming techniques, modern machinery, certified seeds, hybrid seed varieties, pesticides and fertilizer. While, majority of the farmers indulge in traditional ways of farming and remain unaware of latest soil management, water management techniques and technological methods of farming.

\section{Issues \& Challenges Encountered by Farmers}

\begin{tabular}{l|l}
\hline \multicolumn{1}{c|}{ Themes } & \multicolumn{1}{c}{ Responses } \\
\hline Non-Availability of electricity and usage of turbine & $\begin{array}{l}\text { Most of the cases reported that they had the facility of electricity and } \\
\text { used it from } 6 \text { to 10 hours on average. But they were not allowed to } \\
\text { use it for irrigation. Turbine is necessary for irrigation. Although } \\
\text { electricity is available to them but the inability to use turbine is } \\
\text { making it unfeasible. }\end{array}$ \\
\hline In sufficient production and access to market & $\begin{array}{l}\text { Analysis high lights the social exclusion of farmers economically. } \\
\text { Only few farmers have adequate production \& have capacity to sell } \\
\text { their yield in market. However majority of respondents have to face } \\
\text { this crucial issue of low productivity \& market access. }\end{array}$ \\
\hline Interconnectedness with government and NGOs & $\begin{array}{l}\text { All the farmers reported dissatisfaction when asked about the } \\
\text { government and NGOs role and having its membership. } \\
\text { They said that they were poor, due to which there is no one to ask } \\
\text { about their problems. Different organizations are working for farmers } \\
\text { but they do not come to their villages although their villages are a } \\
\text { short distance from city. Several farmers were familiar with the } \\
\text { working of agricultural organization but no one of the respondent } \\
\text { was connected with any agricultural institution for enhancing } \\
\text { productivity. They were dissatisfied with their performance too. }\end{array}$ \\
\hline
\end{tabular}




\section{Conclusion}

The present research was conducted to understand the existence of social exclusion of farmers in arid area of Chakwal district and to find out the dimensions in which they are excluded. On the basis of analysis, we conclude that most of the respondents are excluded from water resources, education to apply modern scientific methods, possession of agricultural machinery \& access to market. The study concluded that farming community lacks proper knowledge and is not properly equipped to meet the challenges of modern agriculture. Majority of the farmers are illiterate and unable to make rational decisions on their own and need institutional support. Moreover, market mechanism is not well established and incapable of providing proper economic signals to all stakeholders. Analysis also depicts that exclusion from one dimension is ultimately making farmers more excluded in other way around. One exclusion is becoming the cause of another for instance farmers lacking sufficient production to sell in the market, results in their inability to purchase essential instruments for sowing, cultivating \& harvesting. Researchers also conclude that if 41 percent of the peoples related to agricultural sector are not in good condition how they will bring forth high production in the modern world to fulfill the need of growing population. The research is very specific to the arid area of Chakwal. It is not for generalization because there can be other factors that are not covered in the context of social exclusion of the farmers like poverty, credit and loan facility and mismanagement in the implementation of policies.

\section{Suggestions}

The importance of social exclusion of farmers can be supplemented by other researchers. The suggestions include:

- This type of research can encourage the government to take reforms regarding awareness campaigns with regards to adopting modern technology and arrange agricultural trainings to enhance the capacity of the farmers.

- The officials of government and nongovernmental agricultural societies can also be interviewed about their ongoing agricultural projects and policies to empower the small farmers.

- The present research was conducted on the exclusion of the rural farmers. It can be used for comparative study by comparing the exclusion of small city farmers with capital city to see who are the most excluded?

\section{References}

Abbas, M., S. Muhammad, I. Nabi and M. Kashif, 2003. Farmers' information sources, their awareness and adoption of recommended sugarcane production technologies in the central Punjab. Pakistan Journal of Agricultural Sciences, 40: 202-206. View at Google Scholar

Atkinson, A.B. and J. Hills, 1998. Exclusion, employment and opportunity. London school of economics. London: Centre for Analysis of Social Exclusion (CASE).

Badar, H., A. Ghafoor and S.A. Adil, 2007. Factors affecting agricultural production of Punjab (Pakistan). Pakistan Journal of Agricultural Sceinces, 44(3): 506-5 10. View at Google Scholar

\section{Bibliography}

De Haan, A., 2000. Social exclusion: Enriching the understanding of deprivation. Studies in Social and Political Thought, 2(2): 22-40. View at Google Scholar

Harrison, P., 1981. The third world tomorrow. Harmondsworth: Penguin.

Jamil, M., 1985. Socioeconomic status of the farmers and their aspiration for the education of their sons. Master's Thesis of Sociology Department: Main Library, University of the Punjab.

Khalil, R., 1973. A study of the attitude of the farmers to cooperate agricultural society in DG khan. Master's Thesis of Sociology Department: Main Library, University of the Punjab.

Sen, A., 1981. Poverty and famines: An essay on entitlement and destitution. Oxford: Oxford University Press.

Silver, H., 1994. Social exclusion and social solidarity: Three paradigms. IILS Discussion Papers No. 69. Geneva: ILO.

Webster, A., 1990. Introduction to the sociology of development. London: British Library. 